\title{
The Power of Sugesti in Traditional Javanese Healing Treatment
}

\author{
Atik Triratnawati $^{1 \bowtie}$, Arsanti Wulandari ${ }^{2}$, Tiara Marthias ${ }^{3}$ \\ ${ }^{1}$ Anthropology Program, Faculty of Humanities, Gadjah Mada University \\ ${ }^{2}$ Nusantara Literature Program, Faculty of Humanities, Gadjah Mada University \\ ${ }^{3}$ Centre of Health Policy and Management, Faculty of Medicine, Gadjah Mada University
}

Permalink/DOI: http://dx.doi.org/10.15294/komunitas.v6i2.3307

Received : July 2014; Accepted: August 2014; Published: September 2014

\begin{abstract}
This paper aims to explore the beliefs in society toward traditional healing regardless of the more accessible, affordable and improved modern health services. This ethnographic study was conducted in Yogyakarta in 20132014. Phenomenological approach was used to analyze the data using the theory of health seeking behavior as the guiding principle of this research. The main factor influencing Javanese community's belief in traditional healing was the power of placebo effect. Placebo can arise from both the patient and the healer. Additionally, other factors such as compatibility between the patients and the healer, patient's aversion to doctor's therapy, and the fact that traditional treatment is cheaper, easier, and more effective than modern medicine were the main considerations for patients in choosing traditional treatment. The benefit of psychotherapy provided through traditional medicine is in the form of life advices or counseling. In addition, healers' attentiveness in listening to patients' complaints was also the main appeal of the traditional health care service.
\end{abstract}

\begin{abstract}
Abstrak
Tulisan ini mengupas kepercayaan masyarakat pada penyembuhan medis tradisional meski pelayanan kesehatan modern semakin mudah diakses, murah/gratis pembiayaannya serta ditingkatkan pelayanannya. Studi etnografis ini dilakukan di DIY tahun 2013-2014. Pendekatan fenomenologi digunakan untuk menganalisis data disertai teori health seeking behavior. Kunci kepercayaan masyarakat Jawa berobat ke penyembuh tradisional adalah pengaruh sugesti. Sugesti muncul baik dari penderita maupun penyembuh. Selain itu faktor cocok, takut dengan terapi dokter serta murah, mudah dan manjur juga menjadi pertimbangan pasien ke pengobatan tradisional. Manfaat psikoterapi berupa nasihat, wejangan maupun saran serta kemampuan penyembuh tradisional mendengarcurahan hati pasien menjadi daya tarik lain pasien merasa cocok kepengobatan non medis.
\end{abstract}

Keywords: sugesti effect; traditional treatment; compatibility; psychotherapy; Javanese culture

How to Cite: Triratnawati, A., Wulandari, A. \& Marthias. T. 2014. The Power of Sugesti in Traditional Javanese Healing Treatment. Jurnal Komunitas, 6 (2): 280-293 doi: 10.15294/komunitas.v6i2.3307

(c) 2014 Semarang State University. All rights reserved 


\section{INTRODUCTION}

Various forms of health insurance in Indonesia such as Askes, JAMKESNAS, Jamkesda, Jampersal or the most recent National Health Insurance (JKN) do not reduce the interest of people to use traditional health service. Traditional health service with the role of traditional healers still claim an important place in the hearts of the people because it can serve as one of the healing treatment options.

Back-to-nature movement in this global era affects people in pursuing their health. Modern people, nowadays, prefer to avoid the use of chemical drugs because of their impact. Therefore, the natural healing, either through herbal medicine or traditional therapies that do not contain toxic substances in the human body, is more attractive. The tendency of the western world to investigate and understand the benefits of the traditional healing is increasing. Complementary and alternative medicines (CAM) as a form of healing through nonwestern medicine which are generally from eastern countries, gain much attention from modern medical science and patients in the developed countries. Therefore, CAM and traditional healers is in great demand due to the increasing interest from people (Encyclopedia of New Medicine, 2006; Kerthyasa, 2013).

In Indonesia, CAM and the practitioners which are increasingly growing in number, have huge influence on the proliferation of advertisements both in the mass and print media. Events at national and local television become a media for traditional healers to increase their therapy's popularity. This condition indicates that CAM seeks to be more publicly known. In addition, the healing method is also displayed to the public so that it will gain people's trust to use CAM.

The percentage of Indonesia's population using traditional medicine in the treatment itself continues to increase over time, from $15.2 \%, 38.3 \%, 62.5 \%$ (CBS, 2010). This trend does not only occur in Indonesian society. People in some developed countries who have high level of modern medical ser- vices also experience the same circumstance. Data mentions that 30\% of Americans use alternative medicine regularly. They visit the health care center of alternative more often than the conventional one. Other countries also vary, such as Denmark 23\%, France $49 \%$, Australia 48.5\%, Taiwan 90\% (Tamtomo, 2012).

There are various types of traditional medicine. High interest of traditional healers can be seen from the increasing practice of traditional medicine. The practice also shows that local knowledge in the field of health is still in the hearts of Indonesian. People still appreciate the legacy of knowledge from the ancestors, although medical practitioners themselves are still often dubious about the benefits and they even prohibit its usage (Sciortino, 1999; Tamtomo, 2012).

However, until now, the study that explores the effectiveness of traditional medicine is rarely found in Indonesia. Even written sources that mention why people believe in traditional medicine than the modern one, as well as what the basic factors of patients believe in the patterns of traditional medicine, are rarely conducted. Social and cultural factors of the patient surely play an important role on their belief in traditional healers (Foster and Anderson, 1987; Triratnawati, 2010).

The purpose of writing this article is to identify the concept of health and the aspect of patients' belief to choose traditional treatment instead of modern one; as well as the factors of sugesti effect underlying patients' belief in the traditional healing.

\section{METHODS}

Data was collected through interview and observation of the traditional healers such as: bekham, sinshe, acupressure, acupuncture, map age, herbal medicine, gurah, religious treatment through prayer, water, herbs, and Javanese treatment as well prana (life force) healing. There was also interview with patients from traditional healer and experts of Javanese culture who understood the topic of traditional healing. There were 24 informants interviewed in their houses 
and in the place of healing practices. The data was collected since July to November 2013 and April 2014. The data was processed based on the results of the interview transcripts, coding and classification. Then, data category was made based on the concept and the most dominant finding.

\section{RESULT AND DISCUSSION}

According to the understanding of Javanese, the concept of health and pain has a comprehensive definition which includes elements of physic, spirit and soul. Spiritual element becomes more important than physical one, because they believe that if someone is spiritually healthy, his physical health will follow. However, if someone is physically healthy, his spiritual health will not necessarily follow. The efforts to make someone spiritually healthy can be done through many ways. Each religion has its own way, such as through fasting, prayer, and meditation. However, for Javanese, being modest which means perih atine or the mind must suffer through meditation is one way to force human spirituality become strong and able to withstand any temptation.

Health and pain are connected to the body. For Javanese, body consists of 3 parts. There is a body in the form of spirit, physic and soul. Spirit or soul is the barrier of good and bad thing as said by a healer G (treatment through herbal and Javanese culture).

Spirit is often referred to as human mind; spirit always warns the physic. Physic, spirit, and soul contain human ambition which never gets satisfied, so that this body should be controlled by the spirit of the human itself. Soul controls human life.

According to Javanese, disease comes from human itself, not from the outside. The disease comes from the human spirit then it goes to the human physic. Disease begins from the element of human nature that is covetous, greedy, and careless which means he is not careful, rigorous, and thorough in his daily behavior including in choosing the food which causes the disease. Human behavior then becomes the cause and sour- ce of all diseases. For Javanese, the effort to prevent the disease more focuses on how humans control the spirit and soul. Controlling the breath is an attempt to balance the rhythm of life. Controlling the breath in modern world can be interpreted as taking exercise or doing physical sport, but for Javanese controlling spiritual breath means controlling soul in order to balance the body and the environment where human lives.

The main healing treatment is to treat the patient spiritually. If the spirit gets the treatment, the physic is also relieved. Meditation, for example, is intended to focus the attention on divinity and to refrain from worldly life and to avoid eating various colors of food. The best food that should be consumed is by eating and drinking something that comes from nature which is free from chemical, flavoring or preservative substances. Body must only consume food with limited quantities because the food in large quantities will only increase worldly lust of human, and human should be able to avoid.

\section{Principle of Javanese Healing}

There are many ways of healing done by Javanese. One way of healing can be different from another although they have the same goal. The Healer G (68 years) states that Javanese songs / ballads (there are 23 ballads) are able to cure the disease. The lyrics of the ballad can case out the demons, crimes and even wars, because the ballad contains requests of prayer to God. If the child had a fever, the Javanese ancestors only sang the ballad in order their child to get better.

Other treatment is to plug the red chili and shallot then put them under the bed of the sick child. Through scientific research, healer $\mathrm{G}$ gives the data that shallot and red chili are element of bacteria repellent. Color is a natural antibiotic wave coming from the plant. Therefore, the healing process does not require drugs but plants are sufficient.

The principle of Javanese healing is similar to Chinese in which there are 5 basic elements in the human body. Those elements are wood (liver), supporting the growth and comfort; water (kidney), cool, 
humidify, reduce, denoted as coolness, fertility; soil (spleen) bearing the burden, giving life, receiving as well as supporting life; fire (heart) warmth, revival; metal (lung) cleaning, eliminating, weakening, the symbol of human nature (lust) which is blazing the heat that cannot stop (Chunjiang, 2003, Kerthyasa, 2013).

Those five elements and one more element which is ether (air) must be in harmony to achieve the health. If one element is not balanced, it will cause pain. Human who has higher level of fire element will cause pain in the heart. In the contrary, human who has higher level of wind element will get abnormality in the liver. Human who has too much amount of water element will get nerve system disorders. Coolness as the symbol of water will describe the pleasures of life which results in laziness. Earth or land as life support will cause the element of fire, water and wind; therefore, these three elements must be in harmony with the element of land.

Sick body must be relieved in order to harmonize other elements. The basic Javanese healing emphasizes the element of harmony or in harmonious. In other word, the treatment in Javanese culture always includes God as the main element which means that God is still number one as an important element in healing, as stated by RM (64 years), the Catholic spiritual healer who provides treatment through water, prayer and lighters.

The Lord Jesus, the son of God always leads good man. God sees the hearts of man. That God created the earth, sky, freezing water, rain all things that contain water. Even people is living like in a fishbowl, if it's in the outer space, the water / overcast and the clouds will look beautiful. God can open his powers including in the healing.

He added that his skill in treating people is a blessing from God. Since childhood, he dreamed of becoming a doctor but he ended up going to school for pastor and he became pastor. Now he realized that the ability to treat someone is in accordance with the duties of a doctor. He added that he always wanted to help people who are in difficulty (sick).

\begin{abstract}
I always ask the patients to pray together at my home yard. They need to be guided in praying because they are the people who are in a difficult situation, confused and sick. They need to feel the joy in order to make their hearts happy. God must bless!
\end{abstract}

\section{Reasons for Choosing Traditional Heal- ing}

The knowledge of Javanese is based on their empirical experiences. The experience is passed down from generation to generation. However, in a globalization era in which everything in this world has been connected rapidly, Javanese society is widely exposed to the elements of modernization and they are able to receive modern medical treatment. Many traditional medical elements then are combined with modern medical components and vice versa. The combination of two or more medical systems that come from different culture occurs. Acculturation of medical system adds to the wealth of cultural treasures of Indonesia in the field of healing method diversity.

Although modern medicine has been accepted by Javanese, the classification of the disease based on the cause of the disease (etiology) still becomes the basis for them to determine the form of treatment. If the etiology is believed to come from the personal circumstance, human as an agent; then healing process will be delivered by the shaman. Meanwhile, if the disease is believed to come from naturalistic circumstance then the healing process will be delivered in modern medical treatment (Foster and Anderson, 1990; Sciortino, 1999; Triratnawati, 2011).

From the statements of the traditional healers after conducting information data cross from patients, some of the reasons why people tend to choose traditional treatment rather than modern one are founded. 


\section{Hopeless expectations of the modern medical treatment}

The numbers of patients with severe disease who fail to be cured by modern medicine (doctors, hospitals) causes them to turn their treatment to the traditional healing. Someone who suffers terribly in his illness must seek for his recovery. In having the treatment, if a therapy does not give any result, this kind of treatment will be abandoned and forwarded to other healing with the same method for example from general practitioners to specialists or subspecialists; or from one shaman to other shaman which is considered to be qualified and have higher level of knowledge. All of the attempts require a good effort, cost and power. All of them are done to cure the patient.

The fact obtained from the description of the patients as well as traditional healers is that most patients come to a traditional healer after they found that modern medicine was no longer able to cope with the disease. The information from herbal healer and prayer B (47 years) is described as follow.

My patients are mostly the former patients of particular doctors, both from leading hospitals in the Province of DIY and other doctors from private practice. My work just deals with receiving secondhand goods.

The remark from healer $\mathrm{B}$ above shows that the patients are generally described as secondhand goods from doctors. This means that the patient had been handled and he visited the doctor for times. He even had surgery. He had hospitalized for long time in the hospital, but he never felt any recovery. Comments are almost similar as given by healer W (67 years, healing through massage, prayer, water and herbs) that stated.

There is my patient, Caucasian people from abroad whose head had been cleaved (surgery). Once he came here I treated him. Thanks God, he is healing. I treat him in my own way, namely massage, prayer and water.

The healer $\mathrm{W}$ often receives patients with severe diseases including leaking heart and cancer, even though he never went to school. He is thankful for his ability in healing gained from the Lord because he is able to help a lot of people from suffering even he treats them in a simple way and without any equipment. Prayed water is believed to be able to cure diseases. In the past, people thought water treatment was only sugesti for healing, but with medical discovery, water can be explained scientifically and rationally (Muyosaro, 2012).

\section{Fear of modern medical therapy}

Not all patients have the same courage to receive the therapy from a doctor. Many patients are afraid of injections. They are even afraid to look at the syringe. There are some who are worried about the surgery, even though the doctor's verdict states that the patient can be cured after the surgery. Frequently, patients with bone fractures are afraid if the doctor places the pins into their bones. Most patients think and feel that the therapy done by doctor is terrible or painful. They imagine that their body is pierced with a needle and drilled to place the pins, or their head is cleaved to describe brain surgery in the head. Horrors and fear of pain (the pain because of the therapy) are always reflected in the patient's mind. Moreover, older age patients (older generation) are often more worried about the doctor therapy. They feel that their body is quite frail and they will not be able to receive therapies that require strong endurance.

Many patients avoid medical therapy because of psychological conditions such as fear, horror and fear of tremendous pain for the doctor therapy. Although the doctors have explained that the patient will receive anesthesia in order to make the patient no longer feel the pain, the fears and worries from the patients cannot be easily removed. Moreover, there is still a lack of understanding from ancient Javanese that once a person has been exposed to the scalpel (surgery) then he will experience it again. This means that the patient will experience another surgery in the same or a different part of his body. 
Therefore, to avoid the therapy from doctor who uses a scalpel, the Javanese is always looking for a safe alternative which is simple yet it is healing. The treatment will be traditional one that does not require any scalpels or syringes and other tools. Traditional therapy is not considered to be creepy. If the pain appears, it will only last for a while and temporary. Although traditional therapy uses massage, pressure, smearing, and even the needling acupuncture, those treatments only last for a while without any pain. Likewise, if drinking the bitter herbs is needed, the patient does not mind doing it. Indeed, feeling of getting better and comfort appear because of the traditional therapy. Although there is a little pain, the patients feel that they make a recovery faster than the doctor treatment which takes a long process, especially the treatment related to bone grafting, nerves and brain.

\section{Fast, effective and inexpensive}

Javanese thought process is strongly influenced by either beliefs or ancient understanding such as Javanese and Hindu, Buddhist, Catholic, Christian, and Islamic beliefs. Reasoning is not considered sufficient to decide anything because it must be accompanied by a sense. Since Javanese know the general and specific diseases (Geertz, 1989), they will choose the treatment based on the belief on the etiology of the disease. In addition, they also believe that the cause of the disease can be categorized into personal circumstance (agent, human as the cause of pain) and natural circumstance (equilibrium model) (Foster and Anderson, 1990; Galanti, 2008). Physical illness is generally treated with modern treatment such as doctor. However, the metaphysical illness should be treated by shaman because only shaman who is capable to cure these diseases.

Patients with bone fractures, for example, are not possible to perform the treatment by themselves. They need a help from the experts. Fractures are automatically curable through subconscious mind but if they are not physically treated, it will cause crooked bone (Praworo, 2011). Modern me- dical treatment requires a long time in the recovery process for bone fractures. Many patients cannot wait long for their recovery. By waiting for a long time recovery, many patients feel that they are wasting time, energy and opportunity to make money. Moreover, patient who comes from lower class and acts as the head of the household states that if he does not work in a single day due to the illness, the other family members even cannot eat any food. In addition, pain is an uncomfortable condition and gives traumatic experience to the patient. Therefore, some patients want to end their suffering in a very short time if it is possible. They then try various methods of healing in order to get fast recovery.

Patients with bone fracture either caused by falling, accident, or crushed by heavy objects certainly take a long time for the healing process to make the bone restored. An orthopedic doctor will perform the process of bone fracture treatment through X-ray method, cast or pins (a metal installed to connect the bones), therefore the healing process requires between 2-3 months. In the hands of traditional healers like sinshe, the experts of fractures, $\mathrm{F}$ (48 years old) mentions that the healing process will be 1 month. Patients only need to be smeared with Chinese herbs for 1-2 months depending on the severity of the fracture. In order to accelerate the healing, patients will also be asked to buy Chinese medicine to heal wounds as well as to join the bones.

Although the patients have to wait long to be served in healing practices of $\mathrm{F}$, the treatment is quite fast for each patient. Patients need to bring the X-ray result from lab / doctor. Then, they will be asked the cause of the fracture. Sinshe reads the Xrays to ascertain the position of the wound. Patients will be asked to remain seated if the fracture is part of the hand and lay if the fracture is the waist part or any part below the waist.

After gathering Chinese powder and Javanese plants with egg albumen, the sinshe will spray anti-infective substance with a spray of Chinese herbs to the body fractures. The sinshe prepares transparent plastic and 
thick cardboard to hold the compound so that the compound remains attached to the part of the body that is being treated. Deftly, he covers the broken part of the body with the Chinese herb and dresses it with bandage and plaster tightly. The patients will be asked to come again after 2 weeks to see the result whether it is already dry and recovered or it needs to be covered one more time. The sinshe will write on paper how to treat the patient with a bandage compound including prescribing Chinese medicine that can be purchased at Chinese drug store near his place. The prescription of Chinese medicine is intended to enhance the healing process with the drug. Practically, the sinshe combines two types of medicine time to get a quick recovery. Sinshe also gives spiritual advice based on the patient's religion. The point is that the patients need to always take care, pray and surrender to the Almighty. The patients should be sure that the way of his healing, they will recover completely.

In terms of payment, if the doctor put the pins based on the pin length, for example, $3 \mathrm{~cm}$ or $4 \mathrm{~cm}$ per $\mathrm{cm}$ and it costs $\mathrm{Rp} 10$ million per $\mathrm{cm}$, then the sinshe gives the same rate for each patient and it is not based on the length of the fracture. Whenever the patients get smeared with the Chinese herb, then the cost paid to the sinshe is much cheaper than the cost of doctor. Although the price is still considered to be expensive, particularly for patients with low income, only by visiting 1-2 times the bone fracture is able to be cured without any complaints. This cost will be much cheaper than the rate of doctor which can reach tens of millions and take a longer recovery process.

This cost is relevant with the quick recovery process, because the patient will be able to return to work more quickly. Thus, the suffering of the pain will end and the patient gets normal life without any help of others anymore. According to the patients, recovery needs to be sought, even if they have to move from one healer to other healers, they will still fight for it. Although recovery is expensive, most family of the patient will endeavor to pay the cost, even by owing or selling goods of his belonging.

\section{Psychological Therapy}

In the globalization era, Javanese also receive the impact. Social interaction is greatly influenced by the mutual needs. They once wasted their time because they thought it could be repeated. Nowadays, time has become a very expensive thing because all people are busy to look for money. Society has changed. The principle of "time is money" becomes a role model in a modern world today. The relationship between family members, relatives and friends are very limited due to the increasingly strong individualism. Confiding something and complaining about life or disease that someone has are difficult to do. This is because all people are so busy or otherwise they are not able to give advice or listen to the complaints. As a result, patients needs help from others, in this case, the healer which is willing to listen to his complaints, not only about his disease but also his personal problems.

In the medical world, the term is known as psychotherapy that is a therapy to raise motivation, passion, and desire of the patient to heal and it is usually conducted for patients with mental disorders through speech, the advice from doctor or psychologist (Galanti, 2008). In general, patients are weak mentally. Therefore, there is a need to build their mental by the healer. The efforts of health maintenance will not succeed if there is no change in the mental attitude (Guang and Lewis, 2012). What traditional healers do is similar to what doctors do. Therefore, the role of traditional healers is like a traditional psychotherapist because they give advice to patients without any special education, but only based on habit. However, the psychotherapy is rarely performed by doctors due to the increasing number of patients. In contrary, traditional healers always have time to do psychotherapy which makes patients feel happy, safe and peaceful.

If someone goes to see a doctor, he has very limited time for consultation. Doctors even tend not to have time to talk, hear complaints and give advice because the number of patients that needs to be served is increasing. The option for going to tradi- 
tional healers becomes the best alternative because the traditional healers are generally willing to share ideas, listen to complaints about patient's illness, and even about family and economic problems. Consultation with traditional healers tends to be unlimited in terms of time. The time is also very flexible. In some cases which traditional healers are highly in demand, the consultation time then becomes limited. However, it is not very rare to find traditional healers who are willing to talk until late at night, as experienced by healer RM. He told that once he did not sleep for 3 months because there were patients who constantly came to him.

\section{The main factor of the recovery: Sugesti Effect}

Among the traditional healers who were interviewed and observed, some of them combined traditional and modern ways of healing. The adoption of modern healing is to ensure the diagnosis. For the disease ascribed to physical disorders / body, they take the advantage of modern medical instruments such as sphygmomanometer. Their diagnosis is based on the results of $\mathrm{x}$-rays to ensure the bone fracture, or other parts of the body as well as the results of laboratory tests. Even the healers of age map, $\mathrm{H}$ (45 years), has principle of $5 \mathrm{D}$ before treating the patients. Principle $5 \mathrm{D}$ are: asking, seeing the map, touching, analyzing and treating in order to get the body recovered as before. The methods of traditional healers do are similar to how doctors treat the patients such as anamnesis, prognosis and therapy (Haruyama, 2013).

The combination of modern and traditional way is not the factor that attracts patients to go to a traditional healer. The main factor, however, is the sugesti effect that underlies the willingness of patients to be cured by traditional healers. Through the sugesti effect, the patient will feel certain, confident and they completely let the ability of traditional healer handle their pain. Strong confidence from the patients becomes support and passion for them to heal. As stated by healer GN ( 42 years).
I definitely give the patients a sugesti. Patients of any religion would be given a sugesti so that they pray, feel certain and confident that their disease will be cured by God. Insya Allah, if patients believe, God will grant the prayers of his servants.

Sugesti is important in Javanese healing process (Pranoto, 200o). Sugesti comes from two sides, namely from the patient and the healer. With the sugesti, the patient will feel certain, confidence and put his trust on the ability of the healer to cure his disease. Feeling great certain and confident about the technique and method of healing such as prayer and herbal medicine/compound given by the healer will certainly encourage the patient to recover. The enthusiasm from the healer through his advice or some restrictions that must be followed by the patient increases his motivation and confidence to recover.

Strong confidence in the patient is the basis of traditional treatment. If the patient has a distrust of the traditional healers' ability from the beginning, he then will not able to be given a sugesti of any treatment done by traditional healers. Therefore, the patient does not feel any benefit of the healing. In contrary, if the patient has great confidence, the patient will feel the benefits after he has completed the therapy performed by traditional healer. The patient's health will gradually get better and he is fully recovered.

In this case, the patient must trust and believe the greatness of healer so that he seems to surrender his fate to the healer. The healers who have the ability to cure through sixth sense (Ferzacca, 2001) will add a sugesti to the patient. The patient's family which take him to the healer's home or place for traditional healing also needs to have a high level of sugesti. This is because family is the person or group who most suffers and sacrifices in seeking the recovery of family members. Many patients come to a traditional healer with condition in which they are not able to walk so they need to be carried by stretcher or wheelchair. There are also many patients who come with crutches and walk with difficulty. Patients with bone fractures 
generally come with a special vehicle (rent) because they are not able to move. When they move, they will feel tremendous pain in the part of their fracture bone. Generally, patients with bone fracture who come to sinshe are lying down on a stretcher.

Patients who came to the traditional healer generally have been treated by doctor but they have not recovered. Therefore, most of their conditions are terribly bad. They need help immediately so that they can go back doing their activity normally without any help of their family. They want to get well very soon so that they do not bother family members as well as his children and grandchildren.

Traditional healers practically also apply the belief that the patient will be able to recover through his own power. The twoway sugesti reinforces the trust from both patient and healer. In self-healing, especially through prayer and mantra, the factor of sugesti also appears that the patient must accept sincerely for the ordeal of God (which makes life), so they have to trust in God's mercy.

Beside the sugesti, some traditional healers also believe that many patients who complain, moan or gripe about the pain as if they were the most miserable person in the world will be more difficult to heal. As argued by the fracture healer $\mathrm{F}$ :

The pain and no pain are actually only in the mouth. Many patients who like to complain and moan usually have a long recovery. While patients who are more calm and resigned to God as well as they sincerely accept the trials and they obey my advice, they actually make a fast recovery.

Not only treatment that uses prayer, massage, sinshe or cupping requires a sugesti. Even drinking herb also needs sugesti. As the experience of the Javanese herb seller and herbalist named M (48 years old) who stated.

I emphasize that before the customers drink the herb they have to read bismil$l a h$, because all treatments come from the
Lord. Herb is only media. They also must feel certain and confident about the herb benefits. Whatever the treatment, they have to be certain. If someone who wants to drink the herb is always anxious and not sure, the herb will not give him any influence.

The description of M shows that drinking herb needs a sugesti. He needs to give the customers the sugesti to make them certain and sure of the traditional herb benefits. At the same time, he warns the customers to always remember God because through God's permission, health problems experienced by a person will bring him to an improvement. By reading Basmallah (referring name of Allah), M believes that God will help him to cure the patient. A sugesti is the key factor of all types and methods of traditional treatment among the Javanese. Sugesti is a method that always appears in every process of traditional treatment. The role of sugesti is very important to give the patients a strong belief to recover. Almost all healers say that this method can be considered as the base of the entire treatment process. If the patient is sincerely sure about the treatment then he will feel a speedy recovery. In contrary, if the patient cannot accept the sugesti given by the healers, then he will get difficulty to heal. If the patient who comes to traditional healer is hesitant even he does not believe and he is not certain or unsure about the ability of the healer, then he cannot get maximum recovery or even he fails to make a recovery. In contrary, someone who comes to him with sincere hearts in order to take and remove his disease, then the recovery will be obtained. As expressed by healer RB (35 years).

If the patient does not believe in the treatment, even he cannot accept the sugesti, the result will be contradictory. The condition of his body will be getting worse.

Practically, all healers state that most patients always believe in the sugesti. Some of healers express almost all patients accept a sugesti given by the healer. To convince the patients, healer $\mathrm{Z}$ (48 years) gives a ter- 
rifying story about the condition of other patients and the expenses paid to have the treatment in the hospital. Through this way, the patient is persuasively suggested to believe in the greatness of God, then the patient will feel more certain and sure on the healing process done by traditional healers done.

A sugesti is made by giving UnenUnen (remark, advice) to the patient either it is expressed implicitly or explicitly. The media of water, prayer, and herbal medicine can also become the effort to increase the sugesti of the patient about the healing. The healers will try to convince the patient that he believes in the healing done by the healers. There are various ways to bring out the sugesti, for example, by suggesting the patient to continue praying and to surrender to God as the One who gives the pain and cure; listening to complaints and problems of the patient; seeing the pain as the evidence of God's love, and so on.

Not only the sugesti which is able to attract patients to go to a traditional healer. Patients of traditional treatment who come from different backgrounds, village, city, education, illness, and age, feel that coming to a traditional healer is easy, cheap, and there is a high trust about the healing method (Supardi, Susyanty, 2010).

\section{Ability healer in treating patients}

The fame of a traditional healer is often determined by the ability to cure the patients. Moreover, if there is patient with a severe disease comes and he is treated once then he recovers, the news will be spread out immediately and automatically the healer is getting well known.

Even though the popularity of the healer is actually known by the people who live far from his place, his neighbors also know about the treatment done by the healer. Neighbors actually know his therapy because many patients come and wait to have the treatment. However, in general, the neighbors will not come to have his treatment. They come to another healer who lives far from them instead. Javanese still believe that if they make more sacrifices, the cure is getting closer. This means that the higher the time, effort, costs spent by the patient, he will be rewarded with the cure. Great sacrifice to get to the place of the healer is considered to be comparable with the recovery process.

Many traditional healers do not want to advertise or place the nameplate for their treatment. According to them, there are various traditional healers, but there are only few healers who are really sincere to help others. Many of them are not genuine and everything is measured with money. Some traditional healers who do not place nameplate are even famous by word of mouth (mouth to mouth) from the patients who had been healed. These patients are like the advertisement which does not need to be paid because they will advertise the greatness of the healer to another person without any order.

Meanwhile, the healers who advertise themselves are considered too commercial because they then have to find the money to pay the advertisement. The cost of advertising is surely taken from the services received from patients. The debate on advertising or system of word of mouth is endless because today is the era of information. The sophistication of technology and the influence of mass media such as radio, leaflets, newspapers, magazines, $\mathrm{TV}$, and internet have attracted traditional healers to advertise in order to be known more widely by people. The mass media also offers to assist traditional healers to get a greater opportunity to raise their revenue. Through advertisement attached with telephone number, complete address and testimony from patients who have been cured by the healers will increase the sale value of their services.

Definitely, there are plus and minus of traditional healers efforts to be further known by the public. There is always aspect of business and economics. Nothing is blamed that traditional healers are people who devote their whole life to help the patient. They also have family that also needs to be supported. Through the services offered by the traditional healers, they can make a living wage.

Related to the service rates, traditional 
treatment varies, from not paying / free, pay as much as the patient can (without tariffs) until the set prices based on the level of difficulty in treatment. The service rate for doctors, specialists and subspecialists, the Indonesian Medical Association has made a limitation even though the rate varies depending on the ability of the people as the patients. Doctors who live in rural and remote area will give a different rate with the doctors who live in big cities especially in the metropolis.

\section{Cocog-cocogan}

Among all factors of patient's recovery, the factor of compatibility (cocog-cocogan) becomes the main thing in traditional treatment (Geertz, 1989). Although a healer is well known for his ability to cure a celebrity, artist or other important persons; he cannot cure a poor patient. It is as stated by a herbal and Javanese healers $G$ ( 68 years).

Although I have cured thousands or hundred thousands of patients, a patient might come to me and he did not recover. However, he was cured after he came to another healer. It means not all patients are suitable with the way of my healing.

He also told that not all the patients with the same type of disease were cured with the same method of healing. There was a couple who were both suffering severe illness and they came to have his treatment. The wife recovered but her husband did not. This case means that healing deals with compatibility which means it can be suitable for someone but not for others.

Although a person is not necessarily compatible with the treatment of traditional healer, trying to come to him is an effort made by most patients. Islam, as it is believed by the majority of Javanese who have treatment from traditional healer, emphasizes that someone who is sick should look for either a modern or traditional treatment as long as it does not deviate from the religion teaching.

Many traditional treatments are based on the verses of holy Quran reading and basmallah. This kind of treatment method is not considered violating religious teachings because there is a prayer sung in the name of God. Therefore, the Javanese who are Muslims are generally more certain to be treated by him since the prayer is in accordance with the his religion teachings.

\section{DISCUSSION}

Health seeking behavior (search patterns of treatment) (Kleinman, 1980) emphasizes the search pattern of healing through the decision-making process which based on cost-benefit analysis. Any pain experienced by the patient such as severe disease will be immediately sought. There is an understanding that the pain will cause a discomfort feeling in the body that affects everyday life including mindset, eating, drinking and inability to work.

Once an individual experiencing pain conditions, he will interpret his health. Although he rejects the truth of general discussion about the disease, he cannot deny that they are explicitly or consciously and unconsciously influenced by the narration of someone who talks about him (Mejer, 2013).

Javanese who have the disease, especially those who have not recovered even though they have been handled by doctor, likely choose traditional treatment. This means that traditional treatment has been used as an alternative healing in addition to modern medical treatment. If we look more closely about the patient's recovery through traditional treatment, almost all healers state that the patients completely recover. Recovery here means that patients no longer feel the symptoms of their disease. Although the pain slowly disappears and they do not recover at once, the patients believe that they are getting better than before. Kerthyasa (2013: 30) cites CAM researchers in many developed countries who find that people who frequently use natural medicine, including herbs, acupuncture, massage have a higher level of health, more rarely experience chronic and degenerative diseases (heart disease, diabetes, cancer). Their expenses for treatment are much lower than people who do not use a natural treatment. 
This finding shows that in terms of costs and health benefits, traditional treatment is beneficial for people. In addition, the healing process is not complicated and does not require long line of queue and registration. The treatment process of traditional healers is not formal, without registration and patient card. The ease of treatment process makes the patients feel comfortable.

There is no definite indicator for the patient's recovery from a traditional healer. Unlike the traditional treatment, modern medical uses definite indicators of healing through clinical examination, laboratory and physical examination done by doctor or other health workers. The recovery of traditional treatment is not based on the medical indicators, but it refers to the psychological and social recovery. Psychological recovery refers to the recovery perceived by the patient himself that he feels healthy and his condition is getting better. Social recovery more focuses on public recognition that the patient has recovered his health and he is able to return doing his normal activities as a healthy person.

Although both modern and traditional medical are able to heal patients but there is difference among them. Some traditional healers mention that the patients' recovery is a medical cure because many traditional healers ask their patients to check to the laboratory and they might come back if they feel they do not completely recover. As stated by religious healer GN ( 42 years old):

If the patient was not sure of his recovery, I would ask him to check into the lab or go to see a doctor.

One of the benefits from traditional healers that patients cannot find in doctor is the advice of life. Healers will give some advises as if they teach their child. The advice given includes spiritual advice. Spirituality is a dimension of health which is generally derived from religious or supernatural powers (Baum, 2008). The advice given is often about knowledge of safety to provide an understanding of how humans live to adjust the physical, mental and spiritual balance in order get a better life which is good, fair and wise so that they are physically and mentally prosperous, peaceful and happy (Hardjodisastro and Hardjodisastro 2010 ). What Javanese miss nowadays is the practice of safety knowledge. Therefore, traditional healers always remind it. Patients feel comfortable, safe and secure with the traditional healers because the healing process is relaxing, without being limited by time, and there is no such a rush. Psychotherapy (pcycho therapy) (GALANTI, 2008) which is given by traditional healers is more beneficial than other therapies using: water, herbal medicine, massage and more.

A sugesti as an important factor in traditional healing is mentioned to be $50 \%$ contributor to the patient's recovery process. Effort to get recovery through sugesti given by the healer becomes dominant in traditional healing. Although modern medicine also recognizes a sugesti from doctor, the sugesti is different with traditional healing process. Traditional healer motivates and prays for the patients so that they have a strong confidence to recover. The healer also gives Javanese spells (Unen-Unen) in order to make the patients surrender to God so that their recovery is quickly obtained. The healer assumes that the patients are actually able to cure their illness (Supandi and Susywaty, 2010)), but through the healing process, power and energy in the patients' body are assisted by the healer to get their stronger power. The sugesti given to patients is important and needs to be done by traditional healer because when someone is sick he is weak both spiritually and physically. The condition of being weak causes patients lack of confidence. When the healer is giving a sugesti to the patients, he tells as if the patients' energy (prana, strength) is weak and needs to be strengthened. In the healing process, the healer seems to act as executioner / angel and tells that the patients' energy is taken which causes them weak. The healer actually says that his positive energy is able to take the disease in the patients' body. Therefore, at the end of the process of healing the healer often says: nggih sampun (yes, already, meaning that 
the disease is already taken). This speech is believed as magic words that are capable to reassure and give great hope for patients in order to end his suffering.

Until now, the medical field still sees the disease from the physical side. A doctor rarely admits that the disease is not only due to physical factors. He often does not believe that the physical disease affects someone's mental which hampers his recovery or even aggravates his condition. Now, western medical begins not to believe a common view that a disease is entirely because of its physics. Physicians begin to learn the concept of eastern medicine (Ariani and Madjid, 2001). In contrast, Javanese has already had an understanding that the body consists of body, soul and spirit that if all three in an unbalanced state, it will cause disease. This kind of understanding needs to be maintained and disseminated so that Javanese generation do not lost their cultural roots about health because even the western people now refer to the eastern science.

The movement of back to nature has influenced humans' life style in the field of health. If modern people want to return to a natural lifestyle and abstain from drug influence which is poisonous, then Javanese has already had a healthy lifestyle because they are more familiar with traditional medicine, the ancestor's heritage, which is simple and free of toxins. However, due to modernity and the influence of foreign culture, Javanese and Indonesian precisely choose modern medical treatment. Western culture has realized the greatness of Eastern medicine. Even Eastern medicine in the research of many experts is believed to be effective in dealing with lifestyle diseases and fatigue (Haruyama, 2013). Therefore, in the current global era, the alternative treatment can be a complement and support which is crucial in the quest for health (Ariani and Madjid, 2001).

\section{CONCLUSION}

According to Javanese, body consists of physical body, soul and spirit. The balance between the elements of the body will result in a healthy condition and the imbalances will result in pain. For Javanese, people who are sick are failed to be cured by modern medicine. Therefore, the traditional treatment becomes an alternative option. The rationality of choosing traditional treatment is caused by many factors. The degree of sugesti effect in the traditional treatment process has great influence on patients' recovery.

\section{REFERENCES}

Ariani, E. \& Madjid, E. 2001. Pengalamanku Berhasil Dengan Pengobatan Alternatif. Jakarta: Majalah Nirmala.

Baum, F. 2008. The New Public Health. Melbourne: Oxford University Press.

Biro Pusat Statistik. 2010. Statistik Kesejahteraan Rakyat, Survei Sosial Ekonomi Nasional 2009. Jakarta: BPS.

Burns, A., Lovich, R., Maxwell, J., et al. 20oo. Pemberdayaan Wanita Dalam Bidang Kesehatan. Yogyakarta: Yayasan Essentia Medica.

Chunjiang, F. 2004. Essence of Traditional Chinese Medicine. Jakarta: Elex Media Komputindo.

Ferzacca, S. 2001. Healing the Modern in a Central Javanese City. Durham: Carolina Academic Press.

Ferzacca, S. 2002. "Governing bodies in New Order Indonesia”, dalam Nichter, M and Lock, M (eds.) New Horizon in Medical Anthropology, London: Routledge.

Foster, G. M. \& Anderson, B. G. 1999. Antropologi Kesehatan. Jakarta: UI Press.

Galanti, A. G. 2008. Caring for Patients from Different Culture. Philadelphia: University of Pennsylvania Press.

Geertz, C. 1989. Abangan, Santri, Priyayi Dalam masyarakat Jawa. Jakarta: Pustaka Jaya.

Guang, H. Z. \& Lewis, V. 2012. Sehat Tanpa Obat: Solusi Sehat, Murah, dan Cepat. Semarang: Dahara Prize.

Hardjodisastro, D., \& Hardjodisastro, W. 2010. Ilmu Slamet. Jakarta: Bhuana Ilmu Populer.

Haruyama, S. 2013. The Miracle of Endorphin. Bandung: Qanita.

Intisari. 2004. Pengobatan Alternatif. Jakarta: PT Gramedia.

Kerthyasa, T. G. 2013. Sehat Alami Secara Holistik. Bandung: Qanita.

Kleinman, A. 1980. Patients and Healers ain the Context of Culture. Berkeley: University of California.

Mejer, J. 2013. Diversity of Medical Discourses and Their Impact Upon Individual's Narrative About Illness in West Sumatra. Komunitas: . 4(1): 128-137.

Muyosaro, P. 2012. Terapi Air Putih. Jakarta: Dunia Sehat.

Pranoto, A. 200o. Saatnya Dukun Bicara. Yogyakarta: Galang Press.

Praworo, K. 2011. Terapi Medipic, Medical Picture. Ja- 
karta: Penebar Plus.

Sanyoto, W. K. 1995. Praktek Aneka Penyembuhan. Pekalongan: Bahagia.

Sciortino, R. 1999. Menuju Kesehatan Madani. Yogyakarta: Pustaka Pelajar.

Supandi, S. \& Susyanty, A. L. 2010. Penggunaan Obat Tradisional Dalam Upaya Pengobatan Sendiri di Indonesia (Analisis Data Susenas Tahun 2007). Buletin Penelitian Kesehatan, 38: 80-89.

Stratern, A. \& Steward, P. J. 1999. Curing and Healing, Medical Anthropology in Global Perspective. Durham: Carolina Academic Press.
The Center of Integrative Medicine at Duke University. 2006. Encyclopedia of New Medicine.

Tamtomo, D. 2012. Keajaiban Kerikan, Murah, Mudah, manjur dan Mesra. Yogyakarta: Citra Aji Parama.

Triratnawati, A. 2010. Pengobatan Tradisional, Upaya Meminimalkan Biaya Kesehatan Masyarakat Desa di Jawa. Manajemen Pelayanan Kesehatan, 13 (2): 69-73.

Triratnawati, A. 2011. Masuk Angin dalam Konteks Kosmologi Jawa. Humaniora. 23 (3): 326-335. 